\title{
Pengkajian Pengembangan Model Pabrikasi Pupuk Organik: Studi Kasus di Kota Tasikmalaya, Jawa Barat
}

\author{
Agus Ruswandi \\ Badan Perencanaan Pembangunan Daerah Provinsi Jawa Barat \\ Jl. Ir. H Juanda No 278- Bandung 40132 Tlp. (022) 2516061 \\ Korespondensi: wandi_ngi@yahoo.com
}

\author{
ABSTRACT \\ Organic Fertilizer Manufacturing Model Developement Assesment: \\ Case Study in Tasikmalaya District, West Java
}

Organic fertilizer manufacturing model has been introduced to the West Java. One of the model has been developed in Tasikmalaya District. The development of model faced some threats, such as institutional problem of organic fertilizer manufacturing and farmers behaviour. The objective of study was 1) to evaluate financial feasibility of organic fertilizer manufacturing in rural area; 2) to find out determining factor in organic fertilizer manufacturing development in rural area; and 3) to find out main factor which influences farmers behaviour in the use of fertilizer. Data were collected through interview to 42 farmers, and expert meeting. Data was analysed by using financial analysis, Margin BCR analysis, and Binary Logistic Regression. Research results indicated that rural-scale organic fertilizer manufacturing by using introduced technology, was feasible. The main problem in rural organic fertilizer manufacture was lower production level than threshold because of weak marketing. The probability of farmers to use organic fertilizer was influenced by proportion of annual plants that been produced, cattle ownership and skill in organic fertilizer mainly in the knowledge of the used of decomposer.

Key words: Feasibility study, organic fertilizer manufacturing, rural area

\begin{abstract}
ABSTRAK
Di beberapa lokasi di Jawa Barat telah diintroduksikan model pabrikasi pupuk organik skala pedesaan antara lain di Kecamatan Tamansari, Kota Tasikmalaya. Dalam pengembangan model tersebut masih menemui beberapa hambatan, yaitu permasalahan dalam pengembangan kelembagaan produksi pupuk organik, serta terkait dengan prilaku petani (pengguna). Pengkajian bertujuan 1) Mengevaluasi tingkat kelayakan usaha pabrikasi pupuk organik di pedesaan; 2) Mengetahui faktor penentu pengembangan produksi pupuk organik di pedesaan; 3). Mengetahui faktor yang mempengaruhi perilaku petani menggunakan pupuk. Pengumpulan data dilakukan melalui Expert Meeting dan survei wawancara terhadap 42 petani responden. Data diolah secara deskriptif, analisis Margin Benefit Cost Ratio, dan analisis regresi logistik binari. Hasil pengkajian menunjukkan bahwa usaha pabrikasi pupuk organik skala pedesaan dengan model introduksi mempunyai kelayakan usaha yang lebih tinggi, sehingga layak dikembangkan. Permasalahan utama pabrik pupuk organik pedesaan yaitu tingkat produksinya masih di bawah kapasitas produksi optimum disebabkan pemasaran hasil yang kurang baik. Peluang petani menggunakan pupuk organik dipengaruhi oleh beberapa faktor yaitu proporsi tanaman semusim yang diusahakan, kepemilikan ternak, serta keterampilan dalam membuat pupuk kompos terutama dalam pengetahuan penggunaan dekomposer.
\end{abstract}

Kata kunci: Studi kelayakan, Pabrik pupuk organik, Pedesaan. 


\section{PENDAHULUAN}

Pupuk organik adalah pupuk yang berasal dari bahan organik, dimana bahan organik merupkan salah satu senyawa penting penyusun tanah. Bahan organik adalah sisa-sisa tanaman atau binatang yang telah mengalami pelapukan seperti pupuk kandang, pupuk hijau, atau kompos (Tandisau, 2005). Saat ini petani lebih suka menggunakan pupuk anorganik karena volume aplikasi pupuk organik lebih besar sehingga memerlukan biaya transportasi yang lebih tinggi (Simanungkalit, 2006). Akibat pemakaian pupuk anorganik yang terus menerus dan kurang diimbangi dengan pupuk organik, telah menurunkan kesuburan lahan. Menurut Suriadikarta \& Simanungkalit (2006) sebagian besar lahan pertanian di Indonesia mempunyai kandungan bahan organik $<$ 2\%. Bahkan menurut Adiningsih (2005) banyak lahan pertanian Indonesia yang mempunyai kadar bahan organik < 1\%. Padahal kadar bahan organik optimum untuk pertumbuhan tanaman sekitar 3\% 5\%. Tanah-tanah dengan kandungan bahan organik rendah mengakibatkan struktur tanah kurang baik untuk pertumbuhan akar tanaman, kapasitas tukar kation menurun, daya sangga tanah terhadap air menurun, aktivitas jasad mikro terhambat dan ketersediaan unsur hara yang mudah tersedia seperti $\mathrm{N}, \mathrm{P}, \mathrm{K}$ dan $\mathrm{S}$ hasil pelapukan bahan organik menjadi menurun (Susanto, 2005). Dengan kondisi tersebut seharusnya permintaan terhadap pupuk organik akan tinggi tetapi kenyataanya tidak demikian (Simanungkalit, 2006). Di tengah kelangkaan pupuk buatan serta berkembangnya pertanian organik, produksi pupuk organik semakin terasa pentingnya.

Kecamatan Tamansari merupakan sentra produksi ternak, terutama domba, di Kota Tasikmalaya yang berpotensi untuk menjadi sumber pendapatan melalui pengolahan kotoran ternak menjadi pupuk kompos. Menurut Setyorini et al.
(2006) pupuk organik dari kotoran ternak merupakan bahan pembenah tanah yang paling baik dibandingkan bahan pembenah lainnya karena menyediakan unsur hara secara lambat dalam jumlah terbatas dan memperbaiki kesuburan dan kesehatan lahan. Hasil penelitian Baharudin (2006) bahwa pemberian pupuk bokasi dari kotoran kambing + EM4 + Jerami + Dedak memberikan prospek yang baik dalam peningkatan produksi lada. Sabran (2008) dalam hasil penelitianya mengemukakan bahwa pemberian pupuk kandang sampai 3 ton/ha meningkatkan hasil kedelai di lahan pasang surut bertanah sulfat masam dari 1,3 ton/ha menjadi 1,9 ton/ha. Pemberian pupuk kandang ayam 2 $\mathrm{Kg} /$ polibag berpengaruh nyata terhadap tinggi tanaman, jumlah daun, diameter batang, berat dan volume buah tanaman melon (Hidayanto, 1999).

Saat ini masih banyak petani yang menggunakan pupuk kandang tanpa dikomposkan terlebih dahulu. Kotoran domba berbentuk butiran akan sulit hancur karena mempunyai nilai $\mathrm{C} / \mathrm{N}$ yang cukup tinggi di atas 30 (Hartatik dan Widowati 2006). Penggunaan pupuk kandang yang belum dikomposkan akan kurang efektif karena sulit diserap tanaman dan mudah terbawa aliran air hujan. Selain itu, kotoran ternak belum dianggap barang ekonomis untuk menambah pendapatan petani-peternak. Dalam upaya pengembangan produksi pupuk organik, di beberapa Lokasi di Jawa Barat, termasuk Kecamatan Tamansari, Kota Tasikmalaya, telah diintroduksikan model pabrikasi pupuk organik pedesaan melalui Program Rintisan dan Akselerasi Pemasyarakatan Inovasi Teknologi Pertanian (Prima Tani). Program ini juga bertujuan untuk mengupayakan perbaikan terknologi pembuatan kompos yang berorientasi pabrikasi (Tabel 1).

Pengembangan model tersebut masih menemui beberapa hambatan, yang diduga terkait

Tabel 1. Perbedaan teknologi antara pola petani dan pola perbaikan

\begin{tabular}{|c|c|c|}
\hline Uraian & Teknologi Pola Petani & Teknologi Pola Perbaikan \\
\hline Bahan Utama & $\begin{array}{ll}\text { - } & \text { Kotoran domba } 75 \% \\
\text { - } & \text { Hijauan tanaman } 25 \% \\
\text { - } & \text { Serbuk gergaji }\end{array}$ & $\begin{array}{l}\text { - Kotoran domba } 80 \% \\
\text { - Arang sekam padi } 10 \% \\
\text { - } \text { Dolomit } 5 \% \\
\text { - Urea } 2,5 \% \\
\text { - SP-36 2,5\% }\end{array}$ \\
\hline Dekomposer & - Dekomposer cara awal : 1 liter & $\begin{array}{l}\text { - Dekomposer cara perbaikan } \\
\text { (Pro Bion) : } 1,25 \mathrm{Kg}\end{array}$ \\
\hline Orientasi & - Tradisional (subsisten) & - Pabrikasi \\
\hline
\end{tabular}


dengan pengembangan kelembagaan pabrikasi pupuk organik serta perilaku petani dalam menggunakan pupuk. Oleh karena itu pengkajian ini bertujuan untuk mengetahui 1) tingkat kelayakan usaha pabrikasi pupuk organik skala pedesaan, 2) masalah pengembangan pabrikasi pupuk organik (kompos) di pedesaan dan 3) faktor yang mempengaruhi perilaku petani dalam penggunaan pupuk.

\section{BAHAN DAN METODE}

Pengkajian dilakukan di Kecamatan Tamansari, Kota Tasikmalaya, pada Bulan Mei- Desember 2009. Lokasi pengkajian ditentukan secara purposive, dengan pertimbangan bahwa Kecamatan Tamansari merupakan salah satu sentra produksi ternak dan pernah diintroduksikan model pabrikasi pupuk kompos.

\section{Pengumpulan dan Analisis Data}

Ada dua jenis data yang dikumpulkan yaitu data primer dan data sekunder. Data sekunder dikumpulkan dari instansi terkait, data primer dikumpulkan melalui wawancara dan expert meeting. Data primer yang dikumpulkan melalui wawancara terhadap 42 petani responden meliputi data input-output pabrikasi produksi pupuk kompos, data perilaku petani dalam penggunaan pupuk organik. Sedangkan data faktor penentu pengembangan model pabrikasi pupuk organik dikumpulkan melalui expert meeting.

Untuk mengetahui tingkat kelayakan usaha dilakukan analisis finansial, sedangkan untuk mengukur tingkat kelayakan teknologi menggunakan analisis Margin Benefit Cost Ratio (MBCR). Analisis ini pernah digunakan oleh Hendayana (2006) untuk mengukur kelayakan teknologi yang diperbaiki dibandingkan dengan teknologi petani pada usahatani padi. Ketentuan analisis MBCR adalah sebagai berikut:

$$
\text { MBCR }=\frac{\begin{array}{l}
\text { Pendapatan usaha pupuk pola perbaikan } \\
- \text { pendapatan usaha pupuk pola petani }
\end{array}}{\begin{array}{l}
\text { Biaya usaha pupuk pola perbaikan } \\
\text { biaya usaha pupuk pola petani }
\end{array}}
$$

dimana:

- Jika nilai MBCR > 1, maka tambahan pendapatan teknologi perbaikan lebih tinggi daripada tambahan biaya. Dengan kata lain, teknologi perbaikan lebih menguntungkan dari ada teknologi petani,
- Jika nilai MBCR < 1, maka tambahan pendapatan teknologi perbaikan lebih kecil dari pada tambahan biaya. Dengan kata lain, teknologi petani lebih menguntungkan dari pada teknologi perbaikan.

- Jika nilai $\mathrm{MBCR}=1$, maka tambahan pendapatan teknologi perbaikan sama dengan tambahan biaya. Dengan kata lain, teknologi perbaikan tidak memberikan tambahan pendapatan.

Untuk mengetahui potensi dan faktor penentu pengembangan model pabrikasi pupuk organik, digunakan data yang diperoleh melalui expert meeting, kemudian data dianalisis secara deskriptif dan diinterpretasikan. Sedangkan untuk mengetahui faktor yang mempengaruhi perilaku petani dalam penggunaan pupuk organik, digunakan analisis model Regresi Logistik Binari (Hosmer dan Lemeshow et al., 1989) dan (Nachrowi et al., 2002). Dalam analisis ini, yang ingin diketahui adalah seberapa besar peluang petani menggunakan pupuk kompos (dinotasikan dengan $\mathrm{W}=1$ ), dan berapa besar peluang petani tidak menggunakan pupuk kompos $(\mathrm{W}=0)$, dengan formulasi sebagai berikut :

$$
P i=\frac{1}{1+e^{-W}}
$$

dimana :

$$
W i=\beta o+\beta 1 V 1+\beta 2 V 2+\ldots .+\beta i V i+\varepsilon
$$

maka,

$$
\begin{gathered}
1-P i=\frac{1+e^{-W i}}{1+e^{-W i}}-\frac{1}{1+e^{-W i}}=\frac{e^{-W i}}{1+e^{-W i}} \\
\frac{P i}{1-P i}=\frac{\frac{1}{1+e^{-W i}}}{\frac{e^{-W i}}{1+e^{-W i}}}=\frac{1}{e^{-W i}}
\end{gathered}
$$

Sehinggga persamaannya dapat dituliskan,

$$
e^{W i}=e^{\beta o+\beta 1 V 1+\beta 2 V 2+\ldots \ldots+\beta i V i+\varepsilon}
$$

Model yang lebih sederhana dapat dituliskan sebagai berikut :

$$
\frac{P(W=1)}{P(W=0)}=e^{W i}
$$

Dengan demikian, 


$$
\ln \left[\frac{P(W=1)}{P(W=0)}\right]=W i
$$

dimana:

$$
\begin{gathered}
W i=\beta o+\beta I V 1+\beta 2 V 2+\ldots . .+\beta i V i+\varepsilon \\
\ln \left[\frac{P(W=1)}{P(W=0)}\right]=\beta o+\beta I V 1+\beta 2 V 2+\ldots \beta i V i+\varepsilon
\end{gathered}
$$

dimana:

$$
\begin{array}{lll}
\mathrm{W} & : \begin{array}{l}
\text { Penggunaan pupuk organik } \\
\text { (Variabel terikat) }
\end{array} \\
\beta 1 \ldots \mathrm{Bi} & : \text { Koefisien variabel tidak terikat } \\
\mathrm{V} 1 \ldots . \mathrm{Vi} & : \text { Variabel bebas } \\
\mathrm{\epsilon} & : \text { Galat }
\end{array}
$$

\section{HASIL DAN PEMBAHASAN}

\section{Karakteristik Bio-Fisik dan Kelembagaan Agribisnis Wilayah Pengkajian}

Sebagian besar wilayah kecamatan Tamansari berupa lahan kering (49,06 \%), dan lahan sawah (39,87\%), dengan topografi yang cukup bergelombang. Salah satu masalah pada jenis lahan tersebut adalah mudah erosi, kesuburan lahan dapat cepat menurun, sehingga perlu adanya konservasi lahan serta asupan hara yang cukup. Masalah tersebut dapat diatasi antara lain melalui pemberian pupuk organik. Dengan demikian pada wilayah dengan kondisi seperti itu, keberadaan pupuk organik merupakan aspek penting dalam upaya meningkatkan pemakaian pupuk berimbang dan konservasi kesuburan lahan, sehingga diharapkan akan tercipta peningkatan pendapatan usahatani secara berkelanjutan. Hal ini sesuai dengan pendapat Krismawati et al., (2005) bahwa pemupukan berdasarkan prinsif keseimbangan hara merupakan salah satu usaha untuk meningkatkan epektivitas mupun efisiensi pemupukan.

\section{Karakteristik Responden}

Karakteristik responden merupakan gambaran karakteristik petani di lokasi pengkajian, sebagai bahan pertimbangan dalam upaya pemanfaatan hasil pengkajian ini ke lokasi lain yang tentunya akan lebih baik apabila diterapkan di wilayah yang karakteristik respondennya hampir sama.
Tabel 2. Karakteristik responden di Kecamatan Tamansari Kabupaten Tasikmalaya

\begin{tabular}{lrrrr}
\hline \multirow{2}{*}{ Jenis lahan } & \multicolumn{4}{c}{ Status lahan garapan responden } \\
\cline { 2 - 5 } & $\begin{array}{c}\text { Milik } \\
\text { (bata) }\end{array}$ & $\begin{array}{c}\text { Garap } \\
\text { (bata) }\end{array}$ & $\begin{array}{c}\text { Jumlah } \\
\text { (bata) }\end{array}$ & $\begin{array}{c}\text { Persen } \\
(\%)\end{array}$ \\
\hline sawah & 91,24 & 21,95 & 113,19 & 33,92 \\
\hline darat & 199,67 & 20,83 & 220,50 & 66,08 \\
\hline jumlah & 290,90 & 42,78 & 333,69 & 100,00 \\
\hline Persen (\%) & 87,18 & 12,82 & 100,00 & \\
\hline
\end{tabular}

Rata-rata jumlah pengusahaan lahan adalah 333,69 bata atau 0,47 ha per kepala keluarga (KK), yang dapat dikatagorikan sebagai petani berlahan sempit. Berdasarkan jenis lahannya, sebagian besar $(66,08 \%)$ merupakan lahan darat, hal ini sesuai dengan agroekologi dominan di Wilayah Kecamatan Tamansari berupa lahan kering dataran rendah. Berdasarkan status lahan, sebagian besar $(87,18 \%)$ merupakan lahan milik. Hal ini cukup penting dalam upaya perbaikan teknologi di wilayah tersebut, dimana petani yang berusaha pada lahan milik, akan lebih leluasa menentukan pilihan alternatif teknologi. Lain halnya pada lahan garapan, pengambilan keputusan akan dipengaruhi oleh pemilik lahan.

\section{Tingkat Kelayakan Model Pabrikasi Pupuk Organik Di Pedesaan}

Model pabrikasi produksi pupuk kompos skala pedesaan diintroduksikan dengan tujuan memperbaiki teknologi dan kelembagaan usaha produksi pupuk organik. Pada Tabel 3 disajikan analisis finansial produksi pupuk organik cara petani dan cara introduksi.

Untuk melaksanakan teknologi perbaikan perlu tambahan biaya produksi, namun dari sisi pendapatan terjadi peningkatan dengan selisih Rp. 174.872 ton $^{-1}$. Peningkatan pendapatan ini disebabkan kualitas pupuk yang dihasilkan menjadi lebih baik dan dapat meningkatkan harga jual dari $\mathrm{Rp} 500 \mathrm{~kg}^{-1}$ menjadi $\mathrm{Rp} 700 \mathrm{~kg}^{-1}$. Berdasarkan keterangan petani pengelola, perbaikan teknologi selain memperbaiki kualitas dan harga jual juga meningkatkan volume penjualan.

Dari sisi kelayakan usaha, produksi pupuk kompos baik dengan teknologi petani maupun dengan teknologi perbaikan cukup menguntungkan, yang ditunjukkan dengan nilai R/C yang lebih dari 1 . Namun demikian, tingkat kelayakan teknologi perbaikan lebih tinggi dibandingkan teknologi 
Tabel 3. Analisis usaha pupuk kompos cara petani dan cara introduksi per ton tahun 2009 per periode produksi

\begin{tabular}{|c|c|c|c|c|c|c|}
\hline \multirow[b]{2}{*}{ Uraian Biaya } & \multicolumn{3}{|c|}{ Teknologi Petani } & \multicolumn{3}{|c|}{ Teknologi Perbaikan } \\
\hline & Jumlah & $\begin{array}{l}\text { Harga } \\
\text { (Rp) }\end{array}$ & $\begin{array}{l}\text { Nilai } \\
\text { (Rp) }\end{array}$ & Jumlah & $\begin{array}{l}\text { Harga } \\
(\mathrm{Rp})\end{array}$ & $\begin{array}{l}\text { Nilai } \\
(\mathrm{Rp})\end{array}$ \\
\hline \multicolumn{7}{|l|}{ Pengeluaran } \\
\hline Biaya Bahan & & & 204.700 & & & 242.328 \\
\hline Biaya Tenaga Kerja & & & 122.500 & & & 110.000 \\
\hline Penyusutan & & & 4.513 & & & 4.513 \\
\hline Total Biaya & & & 331.712 & & & 356.840 \\
\hline Penerimaan & & & & & & - \\
\hline Produksi (Kg) & 1.000 & 500 & 500.000 & 1.000 & 700 & 700.000 \\
\hline Pendapatan Rp) & & & 168.288 & & & 343.160 \\
\hline $\mathrm{R} / \mathrm{C}$ & & & 1,51 & & & 1,96 \\
\hline BCR & & & 0,51 & & & 0,96 \\
\hline
\end{tabular}

petani. Nilai BCR pada teknologi perbaikan lebih tinggi dibanding teknologi petani, yaitu 0,96 . Dengan arti lain, dari modal yang diinventasikan pada teknologi perbaikan menghasilkan pendapatan sebesar $96 \%$. Sedangkan dengan teknologi petani menghasilkan pendapatan sebesar $51 \%$.

\section{Analisis Margin Benefit Cost Ratio (MBCR)}

Teknologi perbaikan dikatakan lebih unggul, bila menghasilkan pendapatan yang lebih tinggi dibandingkan dengan teknologi petani. Tingkat keunggulan teknologi perbaikan dibanding teknologi petani dapat digambarkan oleh nilai MBCR pada Tabel 4.

MBCR bernilai 6,96 (> 1), artinya bahwa teknologi perbaikan lebih unggul dibandingkan teknologi petani. Dengan kata lain, tambahan pendapatan pada teknologi perbaikan lebih tinggi dari tambahan biayanya. Tambahan satu unit biaya akibat penggantian teknologi dari teknologi petani ke teknologi perbaikan, akan menghasilkan tambahan pendapatan sebesar 6,96 kali dari biaya tersebut.

Potensi dan Faktor Penentu Pengembangan Model Pabrikasi Pupuk Organik (Kompos) di Pedesaan Potensi pengembangan pupuk organik

Sejalan dengan semakin berkembangnya pertanian organik, permintaan terhadap pupuk kompos akan terus meningkat. Di pedesaan sentra produksi ternak umumnya tersedia cukup banyak kotoran ternak, yang pada beberapa lokasi masih dianggap sebagai barang yang kurang bernilai ekonomis dan dianggap sebagai barang gratis. Penggunaan kotoran ternak hanya sebatas untuk keperluan sendiri tidak diolah menjadi barang yang lebih bernilai ekonomis

Tabel 4. Analisis MBCR produksi pupuk organik per ton tahun 2009

\begin{tabular}{lrrr}
\hline \multicolumn{1}{c}{ Uraian Biaya } & Teknologi Petani & \multicolumn{1}{c}{$\begin{array}{l}\text { Teknologi } \\
\text { Perbaikan }\end{array}$} & MBCR \\
\hline Pengeluaran & & & \\
1. Bahan (Rp) & 204.700 & 242.328 & \\
2. Tenaga kerja (Rp) & 122.500 & 110.000 & \\
3. Penyusutan alat dan mesin (Rp) & 4.513 & 4.513 & \\
Total Biaya & 331.712 & 356.840 & \\
\hline Penerimaan & & & \\
1. Produksi (Kg) & 1000 & 1000 & \\
2. Harga (Rp/Kg)) & 500 & 700 & \\
3. Penerimaan (Rp) & 500.000 & 700.000 & \\
4. Pendapatan (Rp) & 168.288 & 343.160 & \\
5. R/C & 1,51 & 1,96 & 6,96 \\
6. BCR & 0,51 & 0,96 & \\
\hline
\end{tabular}


menjadi pupuk kompos. Ketersediaan kotoran ternak yang cukup berlimpah dipedesaan akan lebih ekonomis apabila dikembangkan pabrik yang memproduksi pupuk kompos dengan skala pedesaan.

\section{Faktor penentu pengembangan model pabrikasi pupuk organik di pedesaan}

Untuk mengidentifikasi faktor penentu pengembangan model pabrikasi pupuk organik di pedesaan, dikumpulkan data melalui expert meeting yang melibatkan beberapa komponen antara lain Kelompok Tani pengelola pabrik pupuk kompos, petani, Balai Pengkajian Teknologi Pertanian (BPTP) Jawa Barat, Dinas Pertanian setempat, penyuluh pertanian, konsumen pupuk organik, aparat desa dan Bappeda Provinsi Jawa Barat. Dari hasil expert meeting tersebut teridentifikasi faktor utama yang menentukan dalam pengembangan model pabrikasi produksi pupuk organik, yang dapat diklasifikasikan menjadi dua faktor yaitu faktor potensi dan faktor masalah di lokasi pengkajian (Tabel 5).
Tabel 5. Faktor potensi dan faktor masalah dalam Pengembangan model pabrikasi pupuk organik di Kecamatan Tamansari, Kota Tasikmalaya tahun 2009.

\begin{tabular}{|c|c|}
\hline Faktor Potensi & Faktor Masalah \\
\hline $\begin{array}{l}\text { 1) Keberadaan ternak } \\
\text { yang mencukupi } \\
\text { sebagai pemasok bahan } \\
\text { baku (kotoran) di } \\
\text { tingkat lokasi }\end{array}$ & $\begin{array}{l}\text { Tingkat produksi pupuk } \\
\text { kompos masih jauh dibawah } \\
\text { kapasitas produksi }\end{array}$ \\
\hline $\begin{array}{l}\text { 2) Ketersediaan tenaga } \\
\text { kerja yang cukup } \\
\text { berlimpah di pedesaan }\end{array}$ & Pemasaran hasil produksi \\
\hline $\begin{array}{l}\text { 3) Kedekatan tempat } \\
\text { roduksi dengan } \\
\text { produsen (pengguna } \\
\text { pupuk kompos/petani) }\end{array}$ & $\begin{array}{l}\text { Kemampuan permodalan di } \\
\text { tingkat pedesaan/petani }\end{array}$ \\
\hline $\begin{array}{l}\text { 4) Terdapat lembaga } \\
\text { kelompoktani, yang } \\
\text { dapat dijadikan } \\
\text { lembaga basis } \\
\text { pengelola pabrik } \\
\text { pupuk kompos }\end{array}$ & $\begin{array}{l}\text { 1. Keberadaan } \\
\text { program/kegiatan replikasi } \\
\text { model dari intansi terkait. } \\
\text { 2. Keterampilan petani dalam } \\
\text { produksi pupuk kompos. } \\
\text { 3. Tingkat pengetahuan } \\
\text { petani dalam aplikasi } \\
\text { pupuk, khususnya pupuk } \\
\text { organik }\end{array}$ \\
\hline
\end{tabular}

\begin{tabular}{|c|c|c|c|c|c|c|}
\hline Masalah & \multicolumn{3}{|c|}{$\begin{array}{l}\text { Tingkat produksi masih jauh dibawah } \\
\text { kemampuan kapasitas produksi }\end{array}$} & & \multicolumn{2}{|c|}{$\begin{array}{l}\text { Reflikasi model ke wilayah lain } \\
\text { masih lamban }\end{array}$} \\
\hline $\begin{array}{l}\text { Sumber } \\
\text { masalah }\end{array}$ & \multicolumn{3}{|c|}{$\begin{array}{c}\text { Daya serap pembeli } \\
\text { (Pemasaran produksi) masih jauh } \\
\text { dibawah kapasitas produksi }\end{array}$} & \multicolumn{2}{|c|}{$\begin{array}{c}\text { Terbatasnya penganggaran } \\
\text { pemerintah dalam pengembangan } \\
\text { model produksi pupuk organik }\end{array}$} & $\begin{array}{c}\text { Terbatasnya kemampuan } \\
\text { petani dalam teknologi dan } \\
\text { modal }\end{array}$ \\
\hline \multirow[t]{2}{*}{$\begin{array}{l}\text { Akar } \\
\text { masalah }\end{array}$} & \begin{tabular}{|c|} 
Kurangnya pembinan \\
pemasaran dari \\
instansi terkait \\
\end{tabular} & \multicolumn{3}{|c|}{\begin{tabular}{|c} 
Terkait dengan prilaku \\
petani dalam penggunaan \\
pupuk kompos yang \\
masih relatif sedikit \\
\end{tabular}} & $\begin{array}{l}\text { Keterbatasan pengetahuan } \\
\text { petani dalam penggunaan } \\
\text { pupuk kompos }\end{array}$ & $\begin{array}{c}\text { Masih kurangnya, pembinaan } \\
\text { teknologi produksi, dan } \\
\text { dukungan modal }\end{array}$ \\
\hline & \multicolumn{4}{|c|}{\begin{tabular}{|c|} 
Kegiatan instansi terkait terutama dalam \\
pemasaran masih ego sektoral (kurang tersinergi)
\end{tabular}} & & \\
\hline \multirow[b]{2}{*}{$\begin{array}{l}\text { Solusi } \\
\text { masalah }\end{array}$} & \multicolumn{4}{|r|}{ 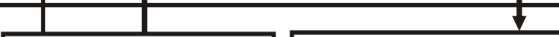 } & $\forall$ & 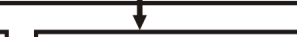 \\
\hline & \multicolumn{2}{|c|}{$\begin{array}{c}\text { Peningkatan pembinaan, } \\
\text { melalui sinergitas kegiatan } \\
\text { antar instansi terkait }\end{array}$} & \multicolumn{2}{|c|}{$\begin{array}{l}\text { Peningkatan kegiatan } \\
\text { pengembangan model } \\
\text { produksi pupuk organik } \\
\text { pada instansi terkait }\end{array}$} & $\begin{array}{l}\text { Peningkatan pengetahuan } \\
\text { petani dalam penggunaan } \\
\text { pupuk kompos }\end{array}$ & $\begin{array}{l}\text { Peningkatan pengetahuan } \\
\text { petani dalam penggunaan } \\
\text { pupuk kompos }\end{array}$ \\
\hline $\begin{array}{l}\text { Kebutuhan } \\
\text { inovasi }\end{array}$ & \multicolumn{5}{|c|}{$\begin{array}{l}\text { 1. Sinergitas kegiatan antar instansi } \\
\text { 2. Teknologi produksi pupuk kompos } \\
\text { 3. Dukungan kelembagaan permodalan } \\
\text { 4. Kemitraan pemasaran pupuk kompos }\end{array}$} & \\
\hline
\end{tabular}

Gambar 1. Masalah pengembangan model pabrikasi pupuk organik 
Berdasarkan faktor masalah dapat diidentifikasi bahwa pemasaran merupakan masalah pokok yang mentukan tingkat produksi pabrik pupuk organik. Tingkat produksi yang dilakukan pabrik pupuk oragnik menyesuaikan permintaan pasar meskipun pada umumnya pabrik tersebut masih mampu untuk meningkatkan kapasitas produksi.

Petani akan tertarik membuat pabrik apabila kemampuan teknologi memadai, bahan baku tersedia, serta modal tersedia. Berdasarkan keterangan dari peserta expert meeting, salah satu bahan penting dalam produksi pupuk kompos adalah dekomposer yang dapat diperoleh dari toko atau diproduksi sendiri. Keterampilan petani dalam memproduksi dekomposer dari bahan baku lokal dapat menjadi pemicu untuk memproduksi pupuk organik (kompos). Namun saat ini, pengetahuan petani terhadap dekomposer umumnya masih masih belum begitu baik. Dengan demikian, peningkatan kemampuan teknologi dekomposer memegang peranan penting dalam upaya pengembangan pabrikasi pupuk organik di pedesaan. Hubungan antar masalah tersebut dapat diilustrasikan dalam bentuk pohon masalah pengembangan model pabrikasi pupuk organik, seperti pada Gambar 1.

\section{Faktor yang Mempengaruhi Perilaku Petani Dalam} Penggunaan Pupuk

Dari hasil analisis Model Regresi Logistik Binari diperoleh data hasil analisis seperti terlihat pada Tabel 6.

Koefisien determinan $\left(\mathrm{R}^{2}\right)$ mempunyai nilai yang cukup besar yaitu 0,739. Hal yang paling penting dalam hasil analisis dengan model ini adalah nilai odd rationya, yang merupakan ukuran peluang terjadinya suatu kejadian ( $\mathrm{Y}=1)$ dibanding dengan peluang kejadian lainnya $(\mathrm{Y}=0)$. Dari hasil analisis di atas dapat diartikan bahwa, jika semua variabel bebas dalam kadaan cateris paribus (bernilai 0), maka peluang terjadinya petani menggunakan pupuk kompos sebesar nilai intersepnya yaitu 0,41 \%. Dengan kata lain, peluang petani menggunakan pupuk organik sangat kecil. Hal ini juga mengindikasikan kecocokan model regresi yang diterapkan ini. Hasil analisis seperti yang diperlihatkan pada tabel 6 mempunyai nilai uji wald lebih besar dari 0, yang berarti bahwa masingmasing variabel tersebut secara parsial signifikan mempengaruhi motivasi petani untuk menggunakan pupuk organik.

Berdasarkan hasil analisis tersebut, motivasi petani dalam menggunakan pupuk kompos secara signifikan dipengaruhi oleh 1) persentase tanaman palawija pada lahannya, 2) keterampilan dalam membuat pupuk kompos, terutama penggunaan dekomposer dan 3) jumlah pemilikan ternak. Semakin besar proporsi luas tanaman semusim akan meningkatkan peluang menggunakan pupuk kompos, tingkat pengetahuan petani terhadap ketersediaan dekomposer secara lokal dapat meningkatkan peluang petani untuk menggunakan pupuk kompos. Semakin tinggi peluang petani tersebut dalam menggunakan pupuk kompos.

\section{SIMPULAN}

Usaha pabrikasi pupuk organik skala pedesaan dengan model introduksi mempunyai kelayakan usaha yang lebih tinggi, sehingga layak dikembangkan meskipun $\mathrm{R} / \mathrm{C}$ dan MBCR untuk pabrik model introduksi lebih tinggi daripada model petani. Nilai MBCR untuk teknologi introduksi adalah $6.69(>1)$ yang mengindikasikan bahwa model

Tabel 6. Analisis faktor yang mempengaruhi petani dalam menggunakan pupuk kompos

\begin{tabular}{lccccc}
\hline \multicolumn{1}{c}{ Variabel Bebas } & B & S.E. & Wald & Sign. & Odd Ratio \\
\hline $\begin{array}{l}\text { Persentase tanaman palawija pada } \\
\text { lahannya (\%) }\end{array}$ & 0,092 & 0,040 & 5,188 & $0,023^{*}$ ) & 1,097 \\
$\begin{array}{l}\text { Mengetahui epektivitas kegunaan } \\
\text { pupuk kompos (Dummy) }\end{array}$ & $-0,155$ & 1,537 & 0,010 & 0,920 & 0,857 \\
$\begin{array}{l}\text { Keterampilan produksi pukpos } \\
\text { (dummy) }\end{array}$ & 4,210 & 1,680 & 6,281 & $\left.0,012^{*}\right)$ & 67,357 \\
Jumlah pemilikan ternak (ekor) & 0.628 & 0,373 & 2,834 & $\left.0,092^{*}\right)$ & 1,873 \\
Konstanta & $-5,500$ & 2,203 & 6,231 & $\left.0,013^{*}\right)$ & 0,004 \\
\hline \multicolumn{7}{c}{$\mathbf{R}^{\mathbf{2}=\mathbf{0 , 7 3 9}}$} \\
\hline
\end{tabular}

.Keterangan : variable terikat : penggunaan pupuk kompos $(\mathrm{Y})$

*) Signifikan pada $\alpha<10 \%$ 
teknologi lebih layak dan dapat dikembangkan di wilayah lain. Masalah utama pendirian pabrik pupuk organik di pedesaan yaitu tingkat produksinya masih di bawah kapasitas produksi optimum karena pemasaran hasil yang kurang baik. Peluang petani menggunakan pupuk organik dipengaruhi oleh beberapa faktor yaitu proporsi tanaman semusim yang diusahakan, kepemilikan ternak, serta keterampilan membuat pupuk kompos.

\section{SARAN}

Usaha pabrikasi pupuk organik di pedesaan cukup menguntungkan, sehingga layak dikembangkan (direplikasi) ke wilayah lain. Tingkat produksi pabrik pupuk organik di pedesaan, sangat bergantung kapada kepastian pemasaran produk sehingga perlu adanya pendampingan/pembinaan dalam pemasaran pupuk organik yang dihasilkan, supaya pabrik tersebut dapat berproduksi sesuai kemampuan kapasitas produksinya. Untuk memacu penyebaran model pabrikasi pupuk organik di pedesaan perlu adanya kepemihakan yang lebih tinggi dari pemerintah yang diindikasikan dengan peningkatan kegiatan pengembangan model pabrikasi pupuk kompos. Pengembangan model pabrikasi pupuk organik harus diarahkan ke wilayah yang dominan mengusahakan tanaman semusim, didukung oleh ketersediaan ternak yang memadai, serta harus disertai dengan upaya peningkatan keterampilan mengolah pupuk kompos, terutama penggunaan dekomposer.

\section{DAFTAR PUSTAKA}

Adiningsih, JS. 2005. Peranan bahan organik tanah dalam meningkatkan kualitas dan produktivitas lahan pertanian. Materi Workshop dan Kongres Nasional II Maporina. Sekretariat Maporina, Jakarta (Tidak Dipublikasikan)

Baharudin dan Sahardi. 2006. Kajian penggunaan pupuk organik dan anorganik terhadap pertumbuhan dan produktivitas lada pada integrasi lada ternak. Dalam Amiruddin Syam., Idris Hadadde., Entis Sutisna., Muh Alwi Mustaha., dan I Wayan Rusastra. 2006. Prosiding Seminar Nasional Akselerasi Inovasi Teknologi Spesifik Lokasi Menuju Pertanian Berkelanjutan, Kendari, 18-19 Juli 2005. Balai Besar Pengkajian dan
Pengembangan Teknologi Pertanian, Bogor. Buku II hal: 661-671.

Hartatik, W dan LR.Widowati. 2006. Pupuk Kandang. Dalam Simanungkalit, R.D.M., Didi Ardi Suriadikarta, Rasti Saraswati, Diah Setyorini, dan Wiwiek Hartatik. Pupuk Organik dan Pupuk Hayati. Balai Besar Penelitian dan Pengembangan Sumber Daya Pertanian, Bogor. Hal. 59-82.

Hendayana, R. 2006. Dampak penerapan teknologi terhadap perubahan struktur biaya dan pendapatan usahatani padi. Dalam Amiruddin Syam., Idris Hadadde., Entis Sutisna., Muh Alwi Mustaha., dan I Wayan Rusastra. 2006. Prosiding Seminar Nasional Akselerasi Inovasi Teknologi Spesifik Lokasi Menuju Pertanian Berkelanjutan, Kendari, 18-19 Juli 2005. Balai Besar Pengkajian dan Pengembangan Teknologi Pertanian, Bogor. Buku I hal: 135-143.

Hidayanto, M. 1999. Pengaruh pemberian pupuk kandang ayam dan pengaruh SP-36 terhadap pertumbuhan dan produksi tanaman melon (Cucumis melo L). Jurnal Pengkajian dan Pengembangan Teknologi Pertanian Volume 2 No 1, Tahun 1999. Pusat Penelitian Sosial Ekonomi Pertanian, Bogor. Hal: 15-18.

Hosmer DW and S Lemeshow. 1989. Applied Logistic Regression. John Wiley and Sons, New York, USA. P. 307.

Krismawati, Amik, M. Anang Firmansyah. 2005. Kajian pupuk alternatif di lahan kering Kalimantan Tengah. Jurnal Pengkajian dan Pengembangan Teknologi Pertanian Volume 8 Nomor 3, Nopember 2005. Pusat Analisis Sosial Ekonomi dan Kebijakan Pertanian, Bogor. Hal: 352-362.

Nachrowi, NJ dan U Hardius. 2002. Penggunaan Teknik Ekonometri. Pendekatan Populer \& Praktis Dilengkapi Teknik Analisis \& Pengolahan Data dengan Menggunakan Paket Program SPSS. PT. Raja Grafindo Persada. Jakarta.

Sabran, M., Koesrini, dan Susilowati. 2008. Kajian penggunaan pupuk kandang pada dua varietas kedelai adaptif di lahan sulfat masam. Jurnal Pengkajian dan Pengembangan Teknologi Pertanian Volume 11 No 3, Nopember 2008. Balai 
Besar Pengkajian dan Pengembangan Teknologi Pertanian, Bogor. Hal: 238-245.

Setyorini, D, R Saraswati dan EK Anwar. 2006. Kompos. Dalam Simanungkalit, R.D.M., Didi Ardi Suriadikarta, Rasti Saraswati, Diah Setyorini, dan Wiwiek Hartatik. Pupuk Organik dan Pupuk Hayati. Balai Besar Penelitian dan Pengembangan Pertanian, Bogor. hal: 11-40.

Simanungkalit, RDM. 2006. Prospek Pupuk Organik dan Pupuk Hayati di Indonesia. Dalam Simanungkalit, R.D.M., Didi Ardi Suriadikarta, Rasti Saraswati, Diah Setyorini, dan Wiwiek Hartatik. Pupuk Organik dan Pupuk Hayati. Balai Besar Penelitian dan Pengembangan Sumber Daya Pertanian, Bogor. Hal: 265-272.

Simanungkalit, R.D.M., Didi Ardi Suriadikarta, Rasti Saraswati, Diah Setyorini, dan Wiwiek
Hartatik. 2006. Pupuk Organik dan Pupuk Hayati. Balai Besar Penelitian dan Pengembangan Sumber Daya Lahan Pertanian, Bogor. Hal: 1-10.

Susanto, A.N. 2005. Pemetaan dan pengelolaan status kesuburan tanah di dataran Wai Apu, Pulau Buru. Jurnal Pengkajian dan Pengembangan Teknologi Pertanian Volume 8 Nomor 3, Nopember 2005. Pusat Analisis Sosial Ekonomi dan Kebijakan Pertanian, Bogor. Hal: 315-332.

Tandisau, Peter., A. Darmawidah A., Warda, dan Idaryani. 2005. Kajian penggunaan pupuk organik sampah Kota Makasar pada tanaman cabai (Capsicum annum L). Jurnal Pengkajian dan Pengembangan Teknologi Pertanian Volume 8 Nomor 3, Nopember 2005. Pusat Analisis Sosial Ekonomi dan Kebijakan Pertanian, Bogor. Hal: 372-380. 